\title{
Ovarian and sperm regulatory peptides regulate ovulation in the oyster Crassostrea gigas
}

\author{
Benoît Bernay ${ }^{1}$, Michèle Baudy-Floc' ${ }^{2}{ }^{2}$, Bruno Zanuttini ${ }^{3}$, Céline Zatylny ${ }^{1}$, \\ Stéphane Pouvreau ${ }^{4}$, Joël Henry ${ }^{1 *}$
}

\begin{abstract}
${ }^{1}$ Laboratoire de Biologie et Biotechnologies Marines, UMR 100 IFREMER Physiologie et Ecophysiologie des Mollusques Marins, Université de Caen, Caen Cedex, France

${ }^{2}$ Laboratoire SESO, UMR CNRS 6510, Institut de Chimie, Université de Rennes I, Rennes Cedex, France

${ }^{3}$ Groupe de Recherche en Informatique, Image et Instrumentation de Caen (GREYC) CNRS UMR 6072

Université de Caen (UFR des Sciences) et ISMRA, Caen, France

${ }^{4}$ Laboratoire de Physiologie des Invertébrés, UMR 100 IFREMER Physiologie et Ecophysiologie des Mollusques

Marins, Site Expérimental d'Argenton, Presqu'île du Vivier, Argenton en Landunvez, France
\end{abstract}

*: Corresponding author : joel.henry@unicaen.fr

\begin{abstract}
For more than six decades, several studies have shown that genital products to entering the mantle cavity via the incurrent siphon, initiate in oyster, strong and rhythmic contractions of the adductor muscle (AM). In order to characterize the regulatory peptides capable of triggering AM contractions, we focused on the identification of putative myotropic peptides from genital products. Two experimental approaches were developed. The first one, based on a mass spectrometry screening of the male genital products, led to the identification of the tetrapeptide APGWamide. This neuropeptide was also detected in the seminal secretions of the cephalopod Sepia officinalis. In this species, APGWamide is directly involved in the oocyte transport. In Crassostrea, in vitro bioassay demonstrated that APGWamide modulates the AM contractions that insure the release of oocytes in the external medium. Exposure of oysters to a physiological concentration of APGWamide triggered repetitive shell closures. The second experimental approach was based on the monitoring of HPLC purification by a myotropic bioassay using the cuttlefish oviduct contractions as a target. The successive purification steps of the acidic extraction of ovaries from mature female oysters, led to the characterization of the hexapeptide PIESVD. When applied to mature female oysters, this peptide triggered the increase of shell closure frequency. The activity of these two regulatory peptides is the first experimental evidence of a peptidergic control of egg-laying in oyster. APGWamide and PIESVD could be used, in commercial and experimental hatcheries, for the identification of mature females to be selected for in vitro fertilization. Mol. Reprod. Dev. @ 2006 Wiley-Liss, Inc.
\end{abstract}

Keywords: Molluscan • egg-laying $\bullet$ APGWamide $・$ myotropin $\bullet$ mass spectrometry 


\section{Introduction}

In the oyster Crassostrea gigas, egg-laying is a complex behavior described by $\mathrm{O}$ Foighil and Taylor [1] as "trans-ctenidial ovulation" (TCO). This behavior involves the coordinated activity of the mantle margins, gills and adductor muscle (AM) and is exclusively restricted to the spawning females. The regulation of TCO by environmental factors has been well described [24]. To date, no regulatory peptides involved in TCO have been identified in oysters, although several studies demonstrate that the addition of a sperm suspension to the water medium triggers egg-laying in mature oysters [5-7]. Furthermore, in most of the observed cases, the release of male products precedes the induction of egg-laying in females. Recently, Rice et al [8] identified from C. virginica an intrinsic sperm membrane protein involved in the regulation of egg-laying. The addition of female genital products of the same specie also triggered spawning from mature females. . In the cuttlefish, Sepia officinalis, the ovarian peptide content involved in the egg-laying regulation was investigated by a myotropic bioassay, using oviduct contractions as an endpoint [9-11]. This bioassay was also used to identify neuropeptides regulating the same egg-laying steps in S. officinalis $[12,13]$. In both C. gigas and S. officinalis, these steps are clearly stereotyped. In oysters, the transport of oocytes through the genital tract is performed by the ciliary motion of the epithelium $[7,14]$. Oocytes are released and stored in the exhalent chamber. Then, they are forced through the gills to the inhalent chamber by highly characteristic AM contractions [6, 15]. Finally, oocytes are released into the external medium, by the AM contractions, through a small spawning window opened between the inhalent chamber mantle margins [5-8, 15-18]. This activity is thought to result in a relatively wide and uniform distribution of oocytes, improving the chances of fertilization. In the cuttlefish, the first step of egg-laying is the release by the ovary of full-grown oocytes (FGO) into the genital coelom [19]. During this period, ovarian factors released by FGO inhibit the oviducal contractions and lead to the accumulation of FGO in the genital coelom [11, 20]. After mating, oocytes transport is performed through the oviduct by the whole genital tract (WGT) contractions which are modulated by neuro- and ovarian peptides $[9,10,12,13]$. Oocytes then received two gelatinous envelopes and are fertilized by spermatozoas stored in the female's copulatory pouch [21, 22]. Finally, the eggs are attached to a substrate until hatching. In both species studied, muscle contractions are responsible for the release of oocytes: AM contractions in oyster and WGT contractions in cuttlefish. In the last six decades, numerous studies have shown that oysters 
initiate a series of strong and rhythmic contractions of the AM in response to genital products entering the mantle cavity via the incurrent siphon $[5-8,23]$. In order to characterize myotropic peptides from male and female genital products in oyster, we developed two experimental approaches. The first one was based on the peptidomic analysis performed on male genital products. The peptidome was screened by means of mass spectrometry using specific sequence libraries. The second experimental approach consisted of the HPLC purification of putative ovarian peptides monitored by the cuttlefish oviduct contractions myotropic bioassay, which is a reliable and specific biological test. 


\section{MATERIALS AND METHODS}

Animals. All the cuttlefish were trapped in the Baie of Seine between January and June. They were maintained in 1000 -liter outflow tanks at $15^{\circ} \mathrm{C}+/ .1^{\circ} \mathrm{C}$ at the Marine Station of Luc sur Mer (University of Caen, France) under a natural photoperiod. Oysters come from Aber Benoît (Bretagne, France) and Saint Vaast la Hougue (Normandie, France).

MicroLC-ESI-MS/MS analysis. Analyses were performed with a HPLC Surveyor chain connected on-line to an orthogonal electrospray source (Deca XP MS-n Thermofinnigan) operated in the positive electrospray ionization mode (ESI+). The ions were focused into an ion trap, capable of MS and MS/MS analyses. The mass spectra were acquired during $35 \mathrm{~ms}$ from $\mathrm{m} / \mathrm{z} 300$ to 2000 . The capillary exit of the electrospray ion source was set at $70 \mathrm{~V}$, the octapole at 3 $\mathrm{V}$ and the capillary temperature at $200^{\circ} \mathrm{C}$. A counter flow of nitrogen was used as nebulizing gas. An Xcalibur data system was used to acquire the data, which were further processed with Turbo Sequest data system. The organic fraction of each extract was resuspended in $10 \mu \mathrm{L}$ of $0.1 \%$ formic acid in water and injected onto a C18 Thermo Hypersil column $(50 \times 0.5 \mathrm{~mm}, 3 \mu \mathrm{m})$ with an acetonitrile linear gradient of $3 \%$ per minute in formic acid $0.1 \%$, from 2 to $60 \%$. A split ratio of 30: 1 was used to perfuse the column at a flow rate of $10 \mu \mathrm{L} / \mathrm{min}$. HPLC column was rinsed with $90 \%$ acetonitrile in $0.1 \%$ formic acid between each injection. The MS data was acquired in scan mode considering the positive ion signal.

In vitro bioassay. The myotropic bioassay was performed with several contractile organs: the WGT, the penis and the vas deferens from S. officinalis and the AM from C. gigas. Each organ was suspended from a displacement transducer (Phymep, Bionic Instruments) connected to a computer controlling the recorder and the DATAC (Dispositif d'Acquisition et de Traitement Automatique de la Contraction). The muscle chamber was perfused at the flow rate of 0.5 $\mathrm{mL} / \mathrm{min}$ with synthetic seawater (Instant Ocean) containing $1 \mathrm{mM}$ glucose and maintained at $15^{\circ} \mathrm{C}$. The samples were injected in the perfusing flow using a three-way valve in order to avoid mechanical and thermal stress. The flow of fractions into the muscle chamber was traced by addition of phenol red. 
In vivo bioassay: shell closure frequency. Oysters were placed at $4^{\circ} \mathrm{C}$ out of water the night before the bioassay. During the experiment, each oyster was placed at $22^{\circ} \mathrm{C}+/ .1^{\circ} \mathrm{C}$, in a $450 \mathrm{~mL}$ tank containing an algal cocktail (25\% Tetraselmis sp., 25\% T. iso, 25\% Chaetoceros calcitrans and $25 \%$ Skeletonema costatum) adjusted to 30 cells per micro liter. Water was circulated in each tank to ensure opening of the valves and filtration by the animals. Following addition of sample, the shell closure frequency was visually monitored during the subsequent assay period (10 minutes). Shell movements during female spawning period are so typical that they cannot be mistaken from any other type of muscular activity (Galtsoff 1938a).

Synthetic peptides. Peptides were synthesized using classical Fmoc (N-[9-fluorenyl] methoxycarbonyl) solid-phase chemistry and a commercially available automated peptide synthesizer by coupling Fmoc- $\alpha$-amino acids on preloaded Wang resin. Protected amino acids were coupled by in situ activation with diisopropylcarbodiimide (DIPCDI) and $N$ hydroxybenzotriazole (HOBt). $N^{\mathrm{a}}$-Fmoc deprotection was performed with $20 \%$ piperidine in DMF. Side chain deprotection and cleavage of peptides from the solid support was performed by treatment with reagent B (88\% trifluoroacetic acid (TFA)/ 5\% Phenol/ 5\% water/ $2 \%$ TIS) for $2 \mathrm{~h}$ at $20^{\circ} \mathrm{C}$ ) [24]. Peptides were purified by reversed-phase HPLC (RP-HPLC) using a Waters semi-preparative HPLC system on an X Terra $10 \mu \mathrm{m}$ column $(300 \times 19 \mathrm{~mm})$. The elution was achieved with a linear gradient of aqueous $0.1 \%$ TFA (A) and $0.08 \%$ TFA in acetonitrile (B) at a flow rate of $10 \mathrm{~mL} / \mathrm{min}$ with photodiode array detection at 210-440 $\mathrm{nm}$. The purity of each peptide was controlled by analytical RP-HPLC on the same instrument with a X Terra $5 \mu \mathrm{m}$ column $(250 \times 4.6 \mathrm{~mm})$ using a linear gradient of $0.1 \%$ TFA in water and acetonitrile containing $0.08 \%$ TFA at a flow rate of $1 \mathrm{~mL} / \mathrm{min}$. Finally, integrity of each peptide was assessed by microLC-ESI-MS/MS analysis.

\section{Sperm peptides}

Recovery of material from tissues. Organs were harvested as follows: for S. officinalis: central nervous system (supra-oesophagal mass, sub-oesophagal mass, optic lobes) and genital tract (vas deferens, seminal vesicles, penis,spermatophores dissected from mature male); for C. gigas: oocytes, mantle edge, gills, labial palpe, smooth muscle and striated muscle of the AM dissected from mature males and females. For microLC-ESI-MS/MS analysis, 5 animal-equivalent of each 
organ studied, 80 animal-equivalent of visceral ganglions, $150 \mathrm{~g}$ of oocytes and $40 \mathrm{~g}$ of sperm from C. gigas were successively homogenized in 10 volumes of $0.1 \mathrm{~N} \mathrm{HCl}$ at $100^{\circ} \mathrm{C}$ and centrifuged 30 minutes at $35000 \times \mathrm{g}$ at $4^{\circ} \mathrm{C}$. The supernatants were concentrated using Chromafix C18 cartridges. In S. officinalis, the spermatophores (complex tubular system containing spermatozoa) were removed from the spermatophoric sacs or Needham's organs and separated into two aliquots. The first aliquot was washed with artificial SW (Instant Ocean) in order to remove seminal secretions. The two aliquots were then extracted as described above.

Identification of regulatory peptides from male genital products. A specific fasta library containing most invertebrates regulatory peptides was created to enable the identification of peptides by MS/MS. Screenings were performed using the Sequest software (Thermofinnigan) which can compare experimental and theoretical MS/MS spectra generated from fasta libraries. For each peptide, the amino acid sequence was definitely confirmed by the comparison between synthetic and endogenic peptide MS/MS spectra.

Bioactivity of APGWamide. Aliquots of synthetic APGWamide (Sigma Aldrich) ranging from $10^{-8}$ to $10^{-6} \mathrm{M}$ were tested using the in vitro and in vivo bioassays in order to obtain qualitative and quantitative data associated with its myotropic activity.

APGWamide oysters in vivo bioassay. Two bioassays were performed with the APGWamide. The first bioassay was performed using 15 oysters and 10-7 M APGWamide for the first sample and 26 oysters and 10-6 M APGWamide for the second sample. The second bioassay was performed with 200 oysters and 10-6 M APGWamide. For each bioassay, the shell closure events were recorded during 10 minutes after injection of the peptide. The experiment was followed by the sacrifice of the animals for sex determination. 
Tissue mapping by microLC-ESI-MS/MS. The occurrence of peptides in the samples was established by the MS/MS data of the m/z 429.5 (APGWa), 459.6 (TPGWa), 486.7 (KPGWa), 514.7 (TPGWa) and 261.2 (GWa). This method detected small amounts of peptide. Peptide identifications were obtained from the comparison of MS/MS spectra of the selected m/z with the synthetic peptides.

\section{Ovarian peptides}

Recovery of material from tissues. For HPLC purification and microLC-ESI-MS/MS analysis, $400 \mathrm{~g}$ of oyster ovaries were homogenized in 4 liters of $0.1 \mathrm{~N} \mathrm{HCl}$ at $100^{\circ} \mathrm{C}$ and centrifuged for 30 minutes at $35,000 \times \mathrm{g}$ at $4^{\circ} \mathrm{C}$. Supernatants were concentrated on Chromafix $\mathrm{C} 18$ cartridges. Moreover, the female genital products released by 5 oysters were extracted in $0.1 \mathrm{~N} \mathrm{HCl}$ at $100^{\circ} \mathrm{C}$, centrifuged and concentrated on Chromafix C18 cartridges.

UV-HPLC purification. HPLC analyses were performed with a Varian 4050 integrator connected to a Varian 9012 solvent delivery system and a Varian 9050 wavelength UV-VIS detector set at $214 \mathrm{~nm}$. The ovary extract was resuspended in $0.1 \%$ formic acid in water and injected onto a Nucleodur C18 column $(250 \times 10 \mathrm{~mm}, 20 \mu \mathrm{m})$ with an acetonitrile linear gradient of $1.33 \%$ per minute in $0.1 \%$ formic acid at a flow rate of $5 \mathrm{~mL} / \mathrm{min}$. A bioactive fraction eluted at 29 minutes and was injected onto a Nucleosil C18 column $(250 \times 3 \mathrm{~mm}, 7 \mu \mathrm{m})$ with an acetonitrile linear gradient of $1.05 \%$ per minute in $10 \mathrm{mM}$ ammonium acetate at a flow rate of $1 \mathrm{~mL} / \mathrm{min}$. The third purification step was performed on a Supelcosil C18 column $(150 \times 4.6 \mathrm{~mm}, 3 \mu \mathrm{m})$ with an acetonitrile linear gradient of $1.33 \%$ per minute in $0.1 \%$ formic acid at a flow rate of $1 \mathrm{~mL} / \mathrm{min}$. Finally, the last step of purification was performed in LC-ESI-MS/MS on a Nucleosil C18 column $(120 \times 4 \mathrm{~mm}, 3 \mu \mathrm{m})$ with an acetonitrile linear gradient of $0.66 \%$ per minute in $0.1 \%$ formic acid at a flow rate of $600 \mu \mathrm{L} / \mathrm{min}$. A split ratio of 100:1 was used to perfuse the electrospray source at a flow rate of $10 \mu \mathrm{L} / \mathrm{min}$. One minute fractions of each step were collected, dried and stored at $4^{\circ} \mathrm{C}$ until use.

Amino acid sequencing. Fasta librairies were generated with the software Aaseq 5.0 (Zanuttini and Henry, University of Caen). Screenings were performed using Sequest software (Thermofinnigan) which is able to compare experimental MS/MS spectra and theoretical MS/MS spectra generated from fasta libraries. The MS/MS spectrum of the amino acid 
sequence was then checked using MS-Tag and MS-Product (Protein Prospector 3.4.1, University of California). Finally, primary structures were verified by Edman degradation. N-terminal sequence analyses were performed using an Applied Biosystems Model 477 A protein sequencer and amino acid phenylthiohydantoin derivatives were identified and quantified on-line with a Model 120A HPLC system, as recommended by the manufacturer.

PIESVD oysters in vivo bioassay. The shell closure bioassay was performed in the middle of June with oysters from Saint Vaast la Hougue, matured in SMEL (Syndicat Mixte pour l'Équipement du Littoral, Blainville). The first bioassay was performed with PIESVD 10-7 M on a sample of 8 oysters and the second on a sample of 39 oysters with PIESVD 10-6 M. Shell closure events were visually recorded during 10 minutes. The experiment was followed by the sarifice of animals for sex determination.

Statistics. Significant differences between treatments were tested by one-way analysis of variance (ANOVA) using the Statistica software. The method used to discriminate among the means was the Student Newman Keuls procedure. Results were deemed significant for $p<0.05$. 


\section{RESULTS}

\section{Regulatory peptides from sperm}

Detection of APGWamide by LC-ESI-MS/MS in male genital products of both studied species. Putative regulatory peptides were investigated by Sequest software using the sequence library of invertebrate regulatory peptides. This approach led to the identification of APGWamide in male genital products of both S. officinalis and C. gigas. The comparison of MS/MS data obtained from synthetic and endogenic peptides confirmed the amino acid sequence (Fig. 1). Furthermore, in the cuttlefish, APGWamide was detected in the seminal fluid coating of spermatophores but not in washed spermatophores demonstrating that APGWamide associated with the seminal fluid.

Bioactivity of APGWamide on S. officinalis male genital tract. For concentrations ranging from $10^{-8}$ to 10-6 M, APGWamide had no effect on penis and proximal vas deferens contractions.

Bioactivity of APGWamide on S. officinalis female WGT. The synthetic peptide was tested on the WGT of mature and immature females. From a threshold at $10^{-7} \mathrm{M}$, APGWamide inhibited the contraction of this tract, decreasing the amplitude and the intensity of the contractions in mature females (data not shown). This biological activity was previously described in [12]. In immature females, APGWamide had no effect on WGT contractions.

Bioactivity of APGWamide on oyster AM. The synthetic peptide was tested on the AM of mature female oysters. From $10^{-7}$ M, APGWamide decreased the intensity of the contractions. In a doseresponse experiment, the increase of concentration appeared to be correlated with the increase of biological activity (Fig. 2).

Shell closure in vivo biological assay. Egg-laying was never triggered during experiments. For the first bioassay, oysters were exposed to $10^{-7} \mathrm{M}$ or $10^{-6} \mathrm{M}$ APGWamide and shell closure events were recorded during 10 minutes. After dissection, we noticed that APGWamide increased shell closure frequency from a threshold of $10^{-7} \mathrm{M}$ on mature females. This peptide had no significant effect on mature males and immature oysters (Fig. 3). A second experiment was performed by exposing 200 oysters to 10-6 M APGWamide. Shell closures were recorded during 10 minutes. Shell closures $(\geq 4)$ were displayed by $41 \%$ of oysters. Sex was confirmed after dissection. 
APGWamide induced shell closure events in $6 \%$ of immature oysters, $30 \%$ of males and $67 \%$ of females. Results are summarized in Figure 4.

APGWa-RPS tissue-mapping by microLC-ESI-MS/MS. Standard MS/MS spectra were acquired from the injection of $1 \mathrm{ng}$ of each of the APGWamide-related-peptides (APGWa-RPs). These spectra were used for the identification of APGWa-RPs in the tissues of S. officinalis and C. gigas. Table 1 summarizes the results obtained for the tissue-mapping performed in the male genital tract and central nervous system (CNS) of S. officinalis. In the male genital tract, APGWa was detected in the spermatophoric glands and TPGWa in the vas deferens. In the CNS, APGWa, TPGWa and GWa were detected in the optic lobes, supra- and sub-oesophagal mass. No APGWamide-related peptides were detected in the hemolymph. Table 2 summarizes the results obtained for the tissue-mapping performed in males and females of $C$. gigas. Only APGWamide was detected in the sperm and visceral ganglions. APGWa-RPs were not detected in somatic tissues.

\section{Ovarian regulatory factors.}

HPLC purification. The purification of oyster oocytes extract was monitored by the cuttlefish oviduct bioassay. After the first purification step, a myotropic activity was detected in the 28-29 min fraction. After two further steps of purification, the activity was concentrated in an apparently pure peak with a retention time of 17-18 min (Fig 5). The last purification step was performed in LC-ESI-MS/MS.

LC-ESI-MS/MS purification. The 17-18 min HPLC fraction, containing the myotropic activity was submitted to LC-ESI-MS/MS purification. The spectrum revealed a pure peak at $\mathrm{m} / \mathrm{z} 659+/-0.5$ (Fig 6). This peak was concentrated to be submitted to Edman degradation.

Sequence determination. Aaseq 5.0 software was used to build a sequence library ranging from 657 to $660 \mathrm{Da}$. The primary sequence of the peptide was partially determined by Sequest software, MS-Tag and MS-Product: PI/LESVD. The primary sequence of this peptide was definitively established by Edman degradation as PIESVD and checked by MS/MS analysis of the synthetic peptide. 
Bioactivity of synthetic peptide. Increasing concentrations of synthetic PIESVD were tested on the WGT of cuttlefish. From a threshold of $10^{-6} \mathrm{M}$, the peptide decreased the intensity of the contractions (Fig. 7).

In vivo bioassay: shell closure frequency. Oysters were exposed to increasing concentrations of synthetic PIESV. Shell closure frequency was visually recorded. From a threshold at $10^{-6} \mathrm{M}$, PIESVD induced a significant increase of shell closure frequency compared to the control in the population of mature females. The peptide had no significant effect on mature males (Fig. 8).

Tissue-mapping by microLC-ESI-MS/MS. Mapping was performed in MS/MS mode based on the $\mathrm{m} / \mathrm{z}$ 659. Analysis performed in the male genital tract, hemolymph and nervous system (visceral ganglions) did not reveal any trace of this peptide. PIESVD was restricted to the ovary. Furthermore, the analysis of the genital products of spawning females clearly established the occurrence of a release of PIESVD during egg-laying. 


\section{Discussion}

Two regulatory peptides isolated from C. gigas were identified by mean of mass spectrometry screening and RP-HPLC purification and provide the first experimental evidence of a peptidergic control of egg-laying in oyster. The first approach, based on a peptidomic analysis, led to the identification of the tetrapeptide APGWamide in male genital products of $C$. gigas. Subsequently, this neuropeptide was detected in seminal secretions of the cuttelfish $S$. officinalis. MicroLC-ESI-MS/MS tissue mapping demonstrated that this peptide is located in the CNS and male genital tract in both oyster and cuttlefish, as well as, according to previous studies, in gastropods, bivalves and cephalopods [25-30]. In cuttlefish, APGWamide is directly involved in oocyte transport [12], whereas in gastropods, APGWamide detected in the male genital tract modulates the male mating behavior [29, 31]. In $S$. officinalis, in vitro bioassays clearly demonstrate that APGWamide has no effect on penis and vas deferens contractions. The APGWamide detected in seminal fluid is deposited with spermatophores in the female copulatory pouch during mating. This pouch contains seminal receptacles surrounded by muscle fibres which could be involved in the storage of spermatophores [22] and may be modulated by APGWamide. We speculate that the APGWamide detected in the oyster CNS (visceral ganglions) could target the AM of mature females, as is described in the sea scallop [25]. Bioassays performed on the AM, which is responsible for the release of oocytes into the external medium, demonstrated that APGWamide induces AM contractions from 10-7 M. When oysters were exposed in vivo, a physiological concentration of APGWamide triggered repetitive shell closures. The in vivo bioassay also demonstrated that a majority of mature females appear to be sensitive to APGWamide (67\% of females compared to only $30 \%$ of males). Moreover, when shell closures were observed, the frequency was higher in females. Contractions observed in the male population could be a consequence of the successive hermaphrodism of C. gigas [18, 32]. Galtsoff demonstrated that although sex change was characterized by modifications in the spawning behavior, a developed female reaction could appear in sex-reversed males [18]. Furthermore, we suspect that the APGWamide detected in the visceral ganglions targets longitudinal and circular muscle fibers of the genital channel [7]. A similar observation was made in the sea scallop, where APGWamide immunoreactivity was found around the gonoduct [25]. In this species, similar investigations led to the detection of 5-HT immunoreactivity around this channel [33]. In vivo experiments clearly demonstrated the involvement of 5-HT in the 
enhancement of oocytes release in bivalves [34-40]. Thus, we speculate that APGWamide and 5HT could be associated in the regulation of oocyte transport through this genital channel. APGWamide could also be involved in the regulation of egg-laying through a second pathway. APGWamide released with male genital products, and detected by mean of mass spectrometry screening, is suspected to target the AM of mature oysters through a pheromonal pathway. However, the effective concentration of $10^{-7} \mathrm{M}$ established with synthetic peptide is much higher than those observed for other water-borne peptides identified in some invertebrates [9-11, 4145]. Yet, it is similar to that observed in the polychaete worm Nereis for the water-borne peptide nereithione involved in male nuptial behavior and sperm release [46, 47]. Similarly, the proximity and high density of mature adults could lead to high concentrations of genital products in the environment surrounding mature females and participate in the regulation of egg-laying in oysters. Hence, the release of oocytes is probably induced by the action of multiple regulatory factors and APGWamide is only one of them. The results from this study using tissue mapping as well as biological activities as endpoints, clearly establish the involvement of APGWamide in the regulation of physiological mechanisms related to egg-laying in C. gigas and S. officinalis. In addition to sperm-linked regulatory peptides, we also focused on the identification of ovarian regulatory peptides, based on regulatory pathways established in the cuttlefish [9, 10, 45]. Following successive steps of UV-HPLC and microLC-ESI-MS/MS purification, a new hexapeptide was characterized from the ovary of mature females based on its ability to modulate the cuttlefish oviduct contractions. The primary structure of this ovarian peptide was established by MS/MS analysis and Edman degradation as PIESVD. MicroLC-ESIMS/MS tissue mapping revealed that this peptide was restricted to the ovary. The occurrence of a release with female genital products in seawater was clearly established by MS/MS analysis. Furthermore, when synthetic PIESVD was added to a rearing tank containing a population of oysters, shell closure frequency increases from a concentration of 10-6 M. This biological activity appears to be restricted to mature females. Thus, we speculate that PIESVD triggers AM contractions through two pathways: (i) when released with oocytes in the exhalant chamber, this peptide targets the AM and ensures the release of oocytes into the external medium, and (ii) through a pheromonal pathway, the PIESVD released by spawning females with genital products could induce the egg-laying behaviour of other mature females in the immediate vicinity. Although the activity threshold of PIESVD is relatively high, the proximity and density of mature oyster populations is consistent with pheromonal activity. The biological activity of 
PIESVD on the cuttlefish WGT demonstrates that some ovarian regulatory peptides could be highly conserved between cephalopods and bivalves and probably among the seven molluscan classes. Indeed, concerning oysters, in vitro bioassays are not reliable enough to monitor the purification of a peptide and in vivo bioassays require large quantities of biological material. Thus, the purification and characterization of regulatory peptides appears to be possible using interspecies bioassays. Finally, APGWamide and PIESVD could be used in commercial as well as in experimental hatcheries, for non-destructive sex and maturity stage determination in oysters. Statistical analysis clearly established that the main targets of APGWamide and PIESVD are the mature females in which they induce an important increase of shell closures. APGWamide and PIESVD, could be used to select mature females in order to provide pure gametes for use in genetic manipulation and in vitro fertilization.

\section{Acknowledgments}

We thank Jean-Marc Nicolas and Darlene Mossman for correcting the English of the manuscript, Didier Rousseville the captain of the professional fishing boat "Père Arthur" and his crew for help in providing cuttlefish as well as Laurence Lafaiteur. We thank Aude Houdan, Bertrand Le Roy, Ian Probert and Algobank for microalgal cultures and Jean Louis Blain, Bertrand Bouchaud and Stéphane Pacary from the SMEL for maturing oysters. This work was supported by the Conseil Regional de Basse Normandie and IFREMER. 
1. O Foighil D, Taylor D. Evolution of parental care and ovulation behavior in oysters. Mol Phylogenet Evol 2000; 15: 301-313.

2. Deslous-Paoli J, Heral M, Berthome J, Razet D, Garnier J. Reproduction naturelle de Crassostrea gigas Thunberg dans le bassin de Marennes-Oleron en 1979 et 1981 : aspects biochimiques et énergétiques. Rev Trav Inst Pêches marit 1982; 45: 319-327.

3. Heral M, Deslous-Paoli J, Prou J. Influence du climat sur le recrutement et sur la production d'huîtres cultivées (C. angulata et $C$. gigas) dans le bassin de MarennesOléron. Haliotis 1986; 15: 193-207.

4. Maurer D, Borel M. Croissance, engraissement et cycle sexuel de C. gigas dans le bassin d'Arcachon: comparaison de huîtres âgées de 1 et 2 ans. Haliotis 1986; 15: 217-228.

5. Galtsoff P. Physiology of reproduction of Ostrea virginica II. Stimulation of spawning in the female oyster. Biol Bull 1938b; 75: 286-307.

6. Nelson T, Allison J. On the nature and action of diantlin; a new hormone-like substance carried by the spermatozoa of the oyster. J Exp Zool 1940; 85: 299-338.

7. Galtsoff P. The American oyster Crassostrea virginica Gmelin. Fish Bull U.S.; 1964.

8. Rice P, Ray SM, Painter SD, Nagle GT. An intrinsic membrane protein in oyster sperm stimulates spawning behaviors in Crassostrea virginica: implications for aquaculture. J Shellfish Res 2002; 21: 715-718.

9. Zatylny C, Gagnon J, Boucaud-Camou E, J H. ILME: a waterborne pheromonal peptide released by the eggs of Sepia officinalis. Biochem Biophys Res Commun 2000b; 275: 217-222.

10. Zatylny C, Gagnon J, Boucaud-Camou E, Henry J. The SepOvotropin: a new ovarian peptide regulating oocyte transport in Sepia officinalis. Biochem Biophys Res Commun 2000c; 276: 1013-1018.

11. Bernay B, Gagnon J, Henry J. Egg capsule secretion in invertebrates: a new ovarian regulatory peptide identified by mass spectrometry comparative screening in Sepia officinalis. Biochem Biophys Res Commun 2004; 314: 215-222.

12. Henry J, Favrel P, Boucaud-Camou E. Isolation and identification of a novel Ala-ProGly-Trp-amide-related peptide inhibiting the motility of the mature oviduct in the cuttlefish, Sepia officinalis. Peptides 1997; 18: 1469-1474.

13. Henry J, Zatylny C, Boucaud-Camou E. Peptidergic control of egg-laying in the cephalopod Sepia officinalis: involvement of FMRFamide and FMRFamide-related peptides. Peptides 1999; 20: 1061-1070.

14. Hoek P. Researches on the generative organs of the oyster (O. edulis). Bulletin of the U.S. Fish Comission 1883; 2: 343-345.

15. Galtsoff P. Physiology of reproduction of Ostrea virginica I. Spawning reactions of the female and male. Biol Bull 1938a; 74: 461-486.

16. Nelson T. Aids to successful oyster culture. I. Procuring the seed. (N J Agr Exp Sta ed. Vol. Bull 351) 1921.

17. Galtsoff $\mathrm{P}$. The role of chemical stimulation in the spawning reactions of Ostrea virginica and Ostrea gigas. Proc Natl Acad Sci U S A 1930a; 16: 555-559.

18. Galtsoff P. Physiology of reproduction in molluscs. Am Zoologist 1961; 1: 273-289.

19. Dhainaut $A$, Richard A. Vitellogenèse chez les céphalopodes décapodes. Evolution de l'ovocyte et des cellules folliculaires au cours de la maturation génitale. Arch Anat Micr Morph Exp 1976; 65: 183-208. 
20. Zatylny C, Durantou F, Boucaud-Camou E, Henry J. Evidence of 5-hydroxytryptamine synthesis in the follicles of Sepia officinalis and direct involvement in the control of egglaying. Mol Reprod Dev 2000a; 55: 182-188.

21. Boletsky S. Sepia officinalis. In: Boyle P (ed.) Cephalopods life cycles, vol. 1. London: Academic Press; 1983: 31-52.

22. Hanlon R, Ament S, Gabr H. Behavioral aspects of sperm competition in cuttlefish, Sepia officinalis (Sepioidea: Cephalopoda). Mar Biol 1999; 134: 719-728.

23. Galtsoff P. Spawning reactions of three species of oysters. J Wash Acad Sci 1932; 22: 6569.

24. Sole N, Barany G. Optimization of solid-phase synthesis of [Ala8]-dynorphin A. J. Org. Chem. 1992; 57: 5399-5403.

25. Smith S, Nason J, Croll R. Detection of APGWamide-like immunoreactivity in the sea scallop, Placopecten magellanicus. Neuropeptides 1997; 31: 155-165.

26. Smit A, Jimenez C, Dirks R, Croll R, Geraerts W. Characterization of a cDNA clone encoding multiple copies of the neuropeptide APGWamide in the mollusk Lymnaea stagnalis. J Neurosci 1992; 12: 1709-1715.

27. Favrel P, Mathieu M. Molecular cloning of a cDNA encoding the precursor of Ala-ProGly-Trp amide-related neuropeptides from the bivalve mollusc Mytilus edulis. Neurosci Lett 1996; 205: 210-214.

28. Henry J, Zatylny C. Identification and tissue mapping of APGWamide-related peptides in Sepia officinalis using LC-ESI-MS/MS. Peptides 2002; 23: 1031-1037.

29. Li K, Smit A, Geraerts W. Structural and functional characterization of neuropeptides involved in the control of male mating behavior of Lymnaea stagnalis. Peptides 1992; 13: 633-638.

30. Fan X, Croll R, Wu B, Fang L, Shen Q, Painter SD, Nagle GT. Molecular cloning of a cDNA encoding the neuropeptide APGWamide and cerebral peptide 1: localization of APGWamide-like immunoreactivity in the central nervous system and male reproductive organs of Aplysia. J Comp Neurol 1997; 387: 53-62.

31. van Golen F, Li K, De Lange R, Van Kesteren R, Van Der Schors R, Geraerts W. Colocalized neuropeptides conopressin and ALA-PRO-GLY-TRP-NH2 have antagonistic effects on the vas deferens of Lymnaea. Neuroscience 1995b; 69: 1275-1287.

32. Amemiya I. On the sex-change of the japanese common oyster, Ostrea gigas Thunberg. Proceedings of the imperial academy (of Japan) 1929; 5: 284-286.

33. Matsutani T, Nomura T. Serotonin-like immunoreactivity in the central nervous system and gonad of the scallop, Patinopecten yessoensis. Cell Tissue Res 1986; 244: 515-517.

34. Khotimchenko Y, Deridovich I. Monoaminergic and cholinergic mechanisms of reproduction control in marine bivalve molluscs and echinoderms: a review. Comp Biochem Physiol C 1991; 100: 311-317.

35. Gibbons MC, Castagna M. Serotonin as an inducer of spawning in six bivalve species. Aquaculture 1984; 40: 189-191.

36. Ram J, Crawford G, Walker J, Mojares J, Patel N, Fong P, Kyozuka K. Spawning in the zebra mussel (Dreissena polymorpha): activatio by internal or external application of serotonin. The Journal of Experimental Zoology 1993; 265: 587-598.

37. Fong P, Duncan J, Ram J. Inhibition and sex specific induction of spawning by serotonergic ligands in the zebra mussel Dreissena polymorpha (Pallas). Experientia 1994; 50: 506-509. 
38. Fong P, Huminski P, D'Urso L. Induction and potentiation of parturition in fingernail clams (Sphaerium striatinum) by selective serotonin re-uptake inhibitors (SSRIs). J Exp Zool 1998; 280: 260-264.

39. Matsutani T, Nomura T. Induction of spawning by serotonin in the scallop Pactinopecten yessoensis (jay). Mar Biol Letters 1982; 3: 353-358.

40. Braley R. Serotonin-induced spawning in giant clams (bivalvia: tridacnidae). Aquaculture 1985; 47: 321-325.

41. Suzuki N. Structure, function and biosynthesis of sperm-activating peptides and fucose sulfate glycoconjugate in the extracellular coat of sea urchin eggs. Zoolog Sci 1995; 12: 13-27.

42. Cummins SF, Schein CH, Xu Y, Braun W, Nagle GT. Molluscan attractins, a family of water-borne protein pheromones with interspecific attractiveness. Peptides 2005; 26: 121129.

43. Cummins SF, Nichols AE, Warso CJ, Nagle GT. Aplysia seductin is a water-borne protein pheromone that acts in concert with attractin to stimulate mate attraction. Peptides 2005; 26: 351-359.

44. Cummins S, Nichols A, Amare A, Hummon A, Sweedler J, Nagle G. Characterization of Aplysia enticin and temptin, two novel water-borne protein pheromones that act in concert with attractin to stimulate mate attraction. J Biol Chem 2004; 279: 25614-25622.

45. Zatylny C, Marvin L, Gagnon J, Henry J. Fertilization in Sepia officinalis: the first mollusk sperm-attracting peptide. Biochem Biophys Res Commun 2002a; 296: 11861193.

46. Zeeck E, Müller C, Beckmann M, Hardege J, Papke U, Sinnwell V, Schroeder F, Francke $\mathrm{W}$. Cysteine-glutathione disulfide, the sperm-release pheromone of the marine polychaete Nereis succinea (Annelida: Polychaeta). Chemoecology 1998; 8: 33-38.

47. Ram J, Muller C, Beckmann M, Hardege J. The spawning pheromone cysteineglutathione disulfide ('nereithione') arouses a multicomponent nuptial behavior and electrophysiological activity in Nereis succinea males. FASEB J 1999; 13: 945-952. 


\begin{tabular}{|c|c|c|c|c|c|}
\hline Occurrence of: & APGWa & RPGWa & KPGWa & TPGWa & GWa \\
\hline Sub-oesophagal mass & $d^{*}$ & nd & nd & $d$ & $d$ \\
\hline Supra-oesophagal mass & $d$ & nd & nd & $d$ & $d$ \\
\hline Optic lobes & $d$ & nd & nd & $d$ & $d$ \\
\hline Male genital tract & $d$ & nd & nd & $d$ & nd \\
\hline Spermatophores & $n d^{*}$ & nd & nd & nd & nd \\
\hline Seminal fluid & d & nd & nd & nd & nd \\
\hline Penis & nd & nd & nd & nd & nd \\
\hline Seminal vesicles & d & nd & nd & nd & nd \\
\hline Vas deferens & nd & nd & nd & $d$ & nd \\
\hline
\end{tabular}

$n d^{\star}$ : not detected $\mathrm{d}^{\star}$ : detected

Table 1. Tissue mapping of APGWamide-RPs in male Sepia officinalis.

\begin{tabular}{lccccc}
\hline \multicolumn{1}{c}{ Occurrence of: } & APGWa & RPGWa & KPGWa & TPGWa & GWa \\
\hline Male and female gills & nd* & nd & nd & nd & nd \\
Male and female mantle edge & nd & nd & nd & nd & nd \\
Male and female smooth muscle & nd & nd & nd & nd & nd \\
Male and female striated muscle & nd & nd & nd & nd & nd \\
Male and female labial palpes & nd & nd & nd & nd & nd \\
Male and female visceral ganglions & d* & nd & nd & nd & nd \\
Female genital products & nd & nd & nd & nd & nd \\
Male genital products & $\mathrm{d}$ & nd & nd & nd & nd \\
\hline
\end{tabular}


A

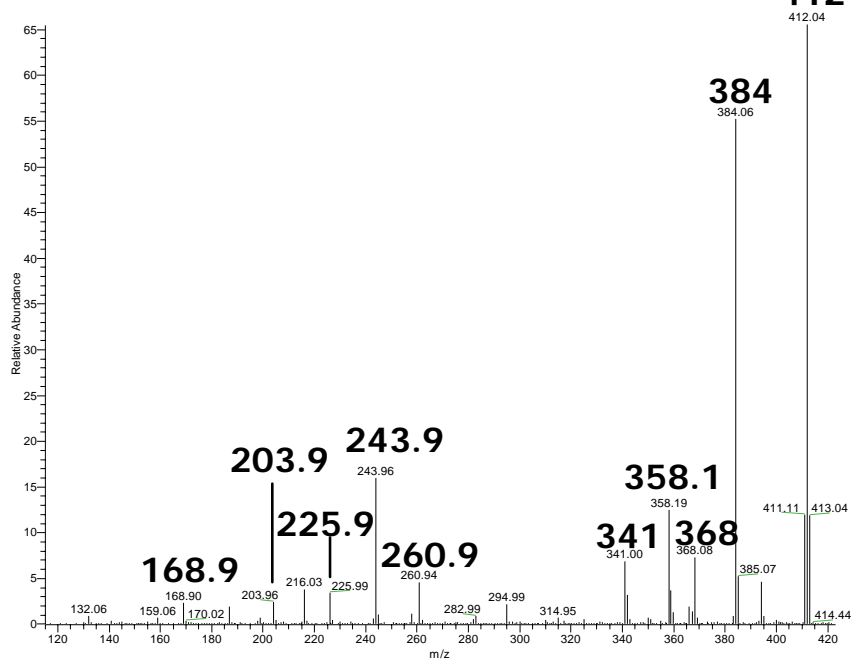

B

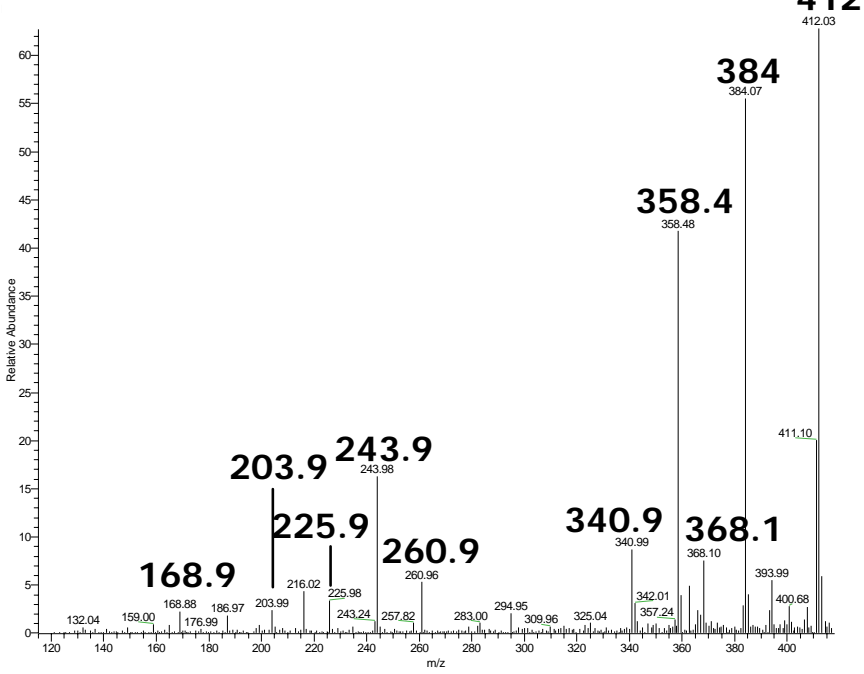

C

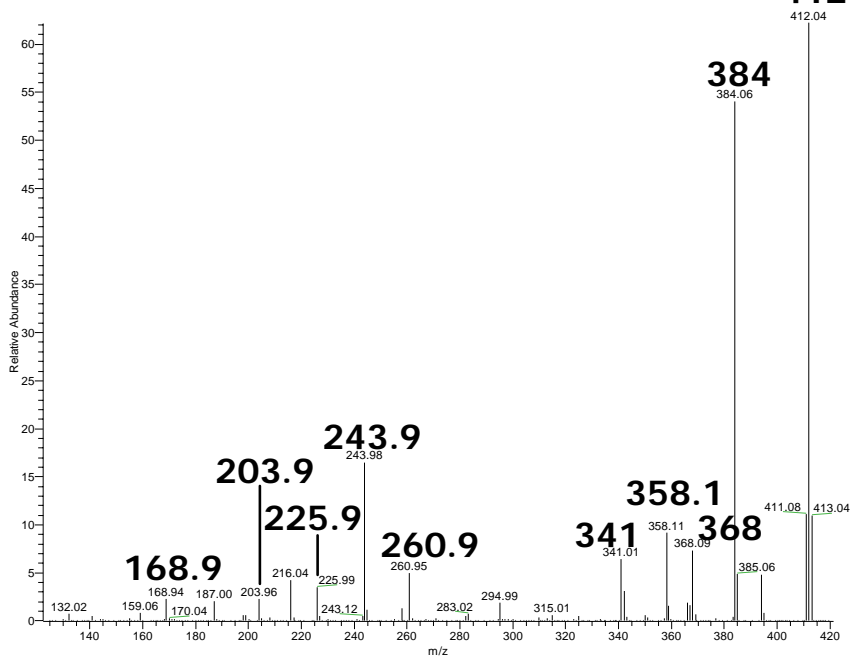

FIG. 1. MS/MS spectra of synthetic APGWa (A) and endogenic APGWa detected in male products of Crassostrea gigas (B) and Sepia officinalis (C). 


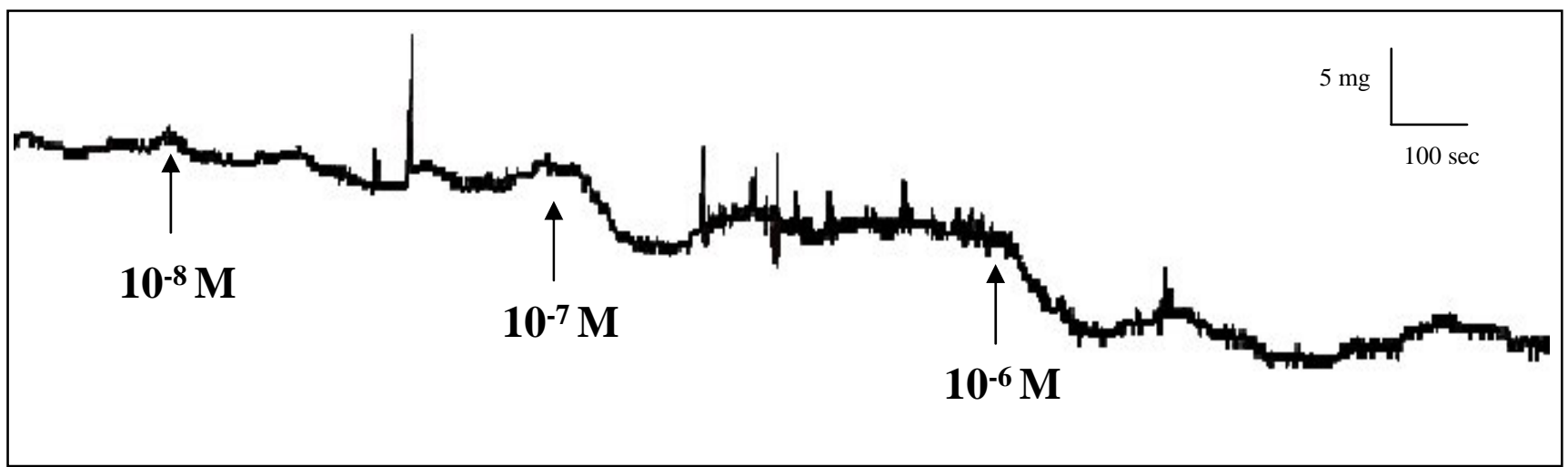

FIG. 2. Dose dependent APGWamide-induced contractions of the adductor muscle of Crassostrea gigas

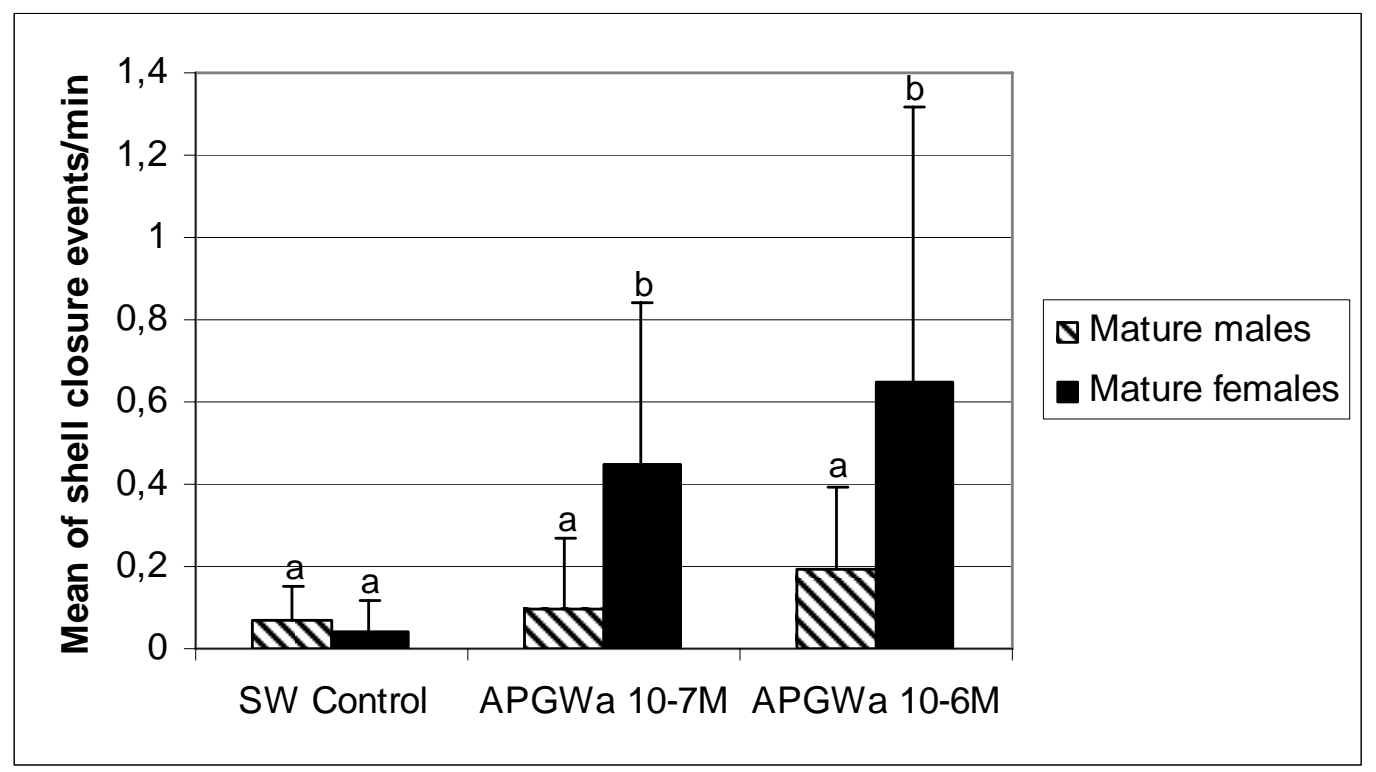

FIG. 3. Shell closure in vivo bioassay. APGWamide-induced contraction of the female adductor muscle of Crassostrea gigas at a threshold of 10-7 M. Letters indicate a significant difference between treatments (mean \pm S.D.; ANOVA, $\mathrm{p}<0.05$ ) 


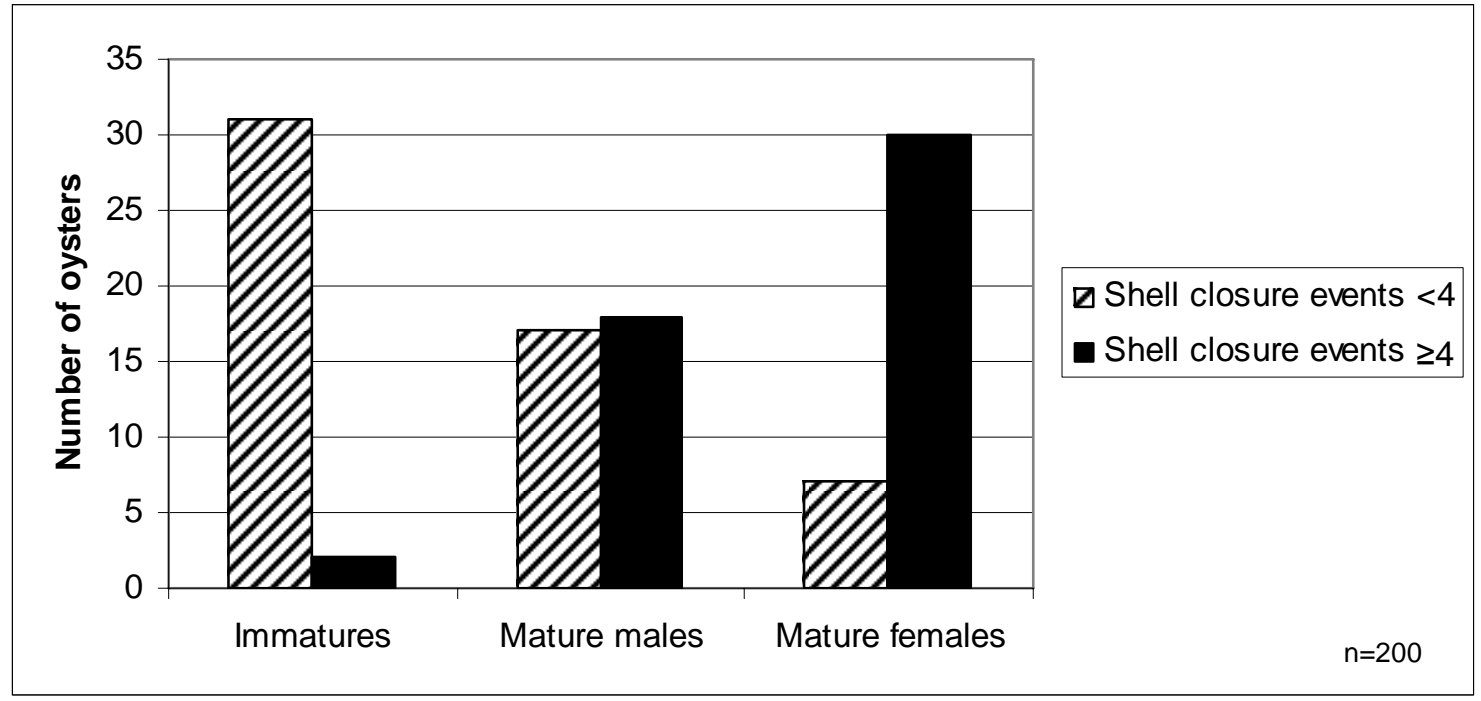

FIG. 4. Shell closure in vivo bioassay performed with APGWamide 10-6 M. APGWamidt _..iggers more shell closures in mature females than in males or immature oysters 

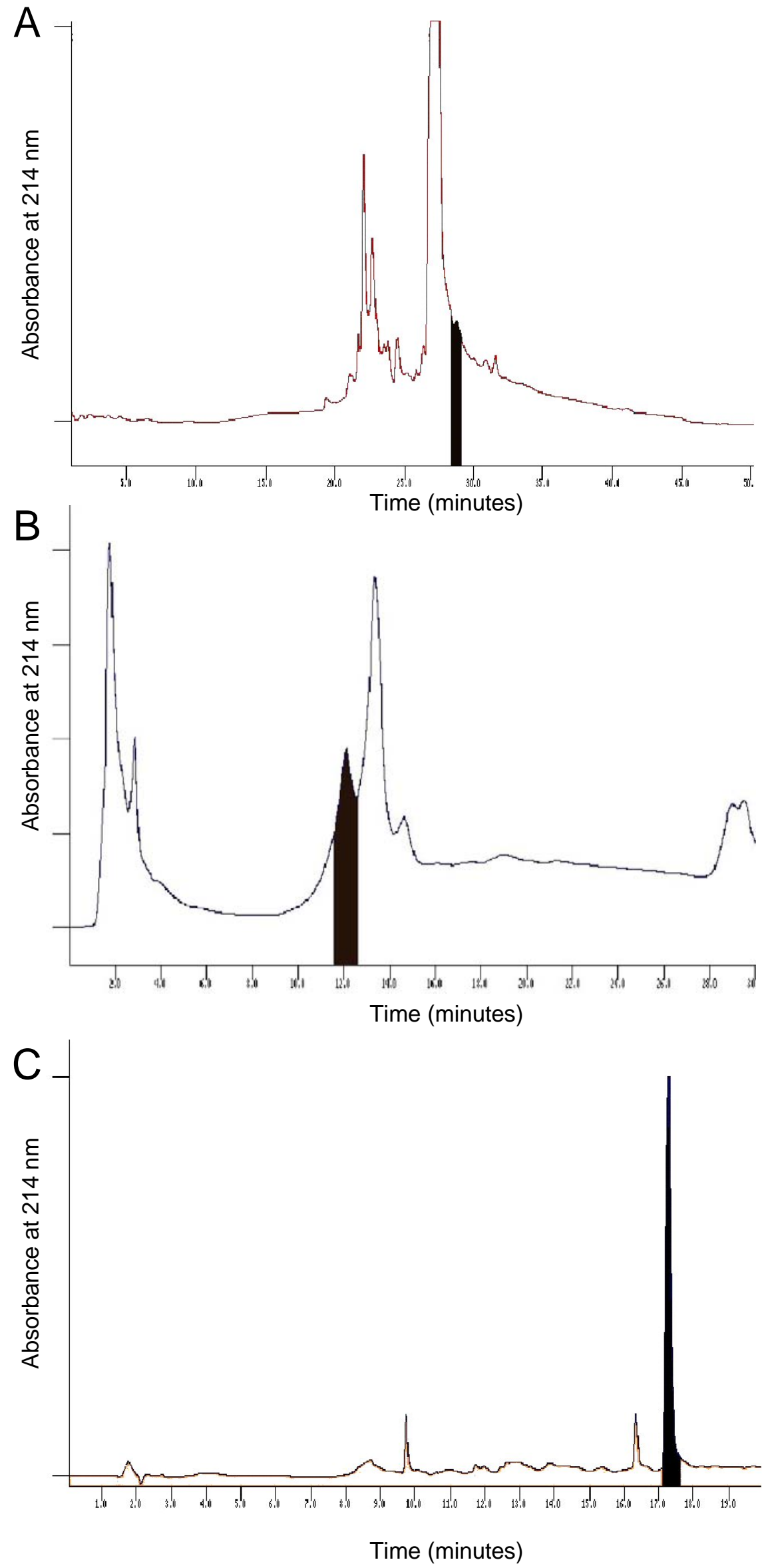

FIG. 5. First (A), second (B) and third (C) purification steps of oyster oocyte extract. Myotropic fractions are indicated in black 

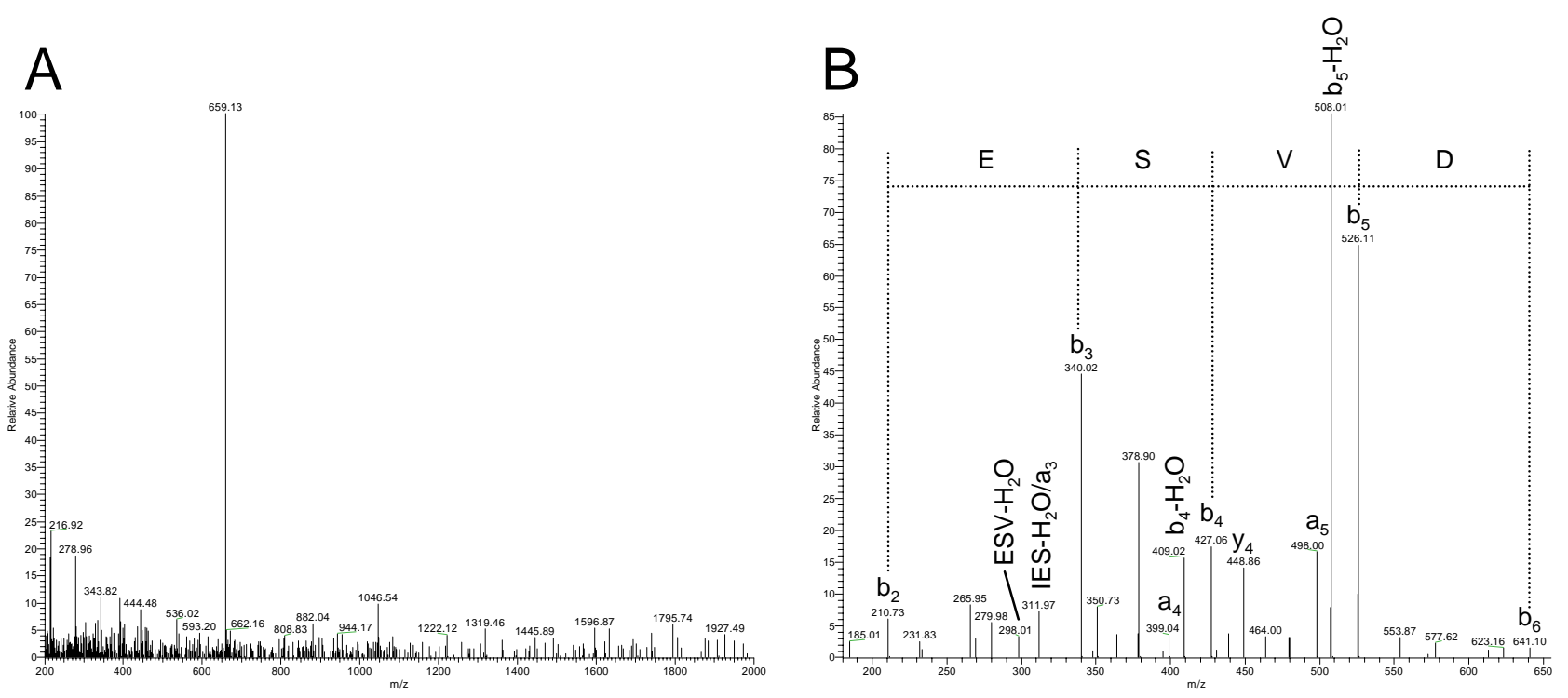

FIG. 6. ESI-MS spectrum of the myotropic HPLC fraction obtained after three steps of purification (A). MS/MS spectra of the $\mathrm{m} / \mathrm{z} 659$ from oyster oocytes (B)

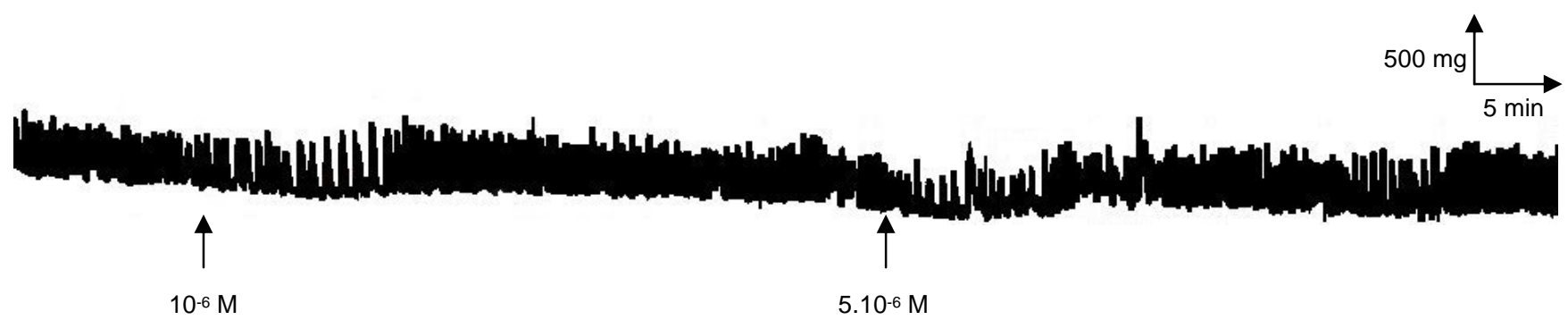

FIG. 7. PIESVD-induced contractions of the cuttlefish whole genital tract at a threshold of 10-6 M

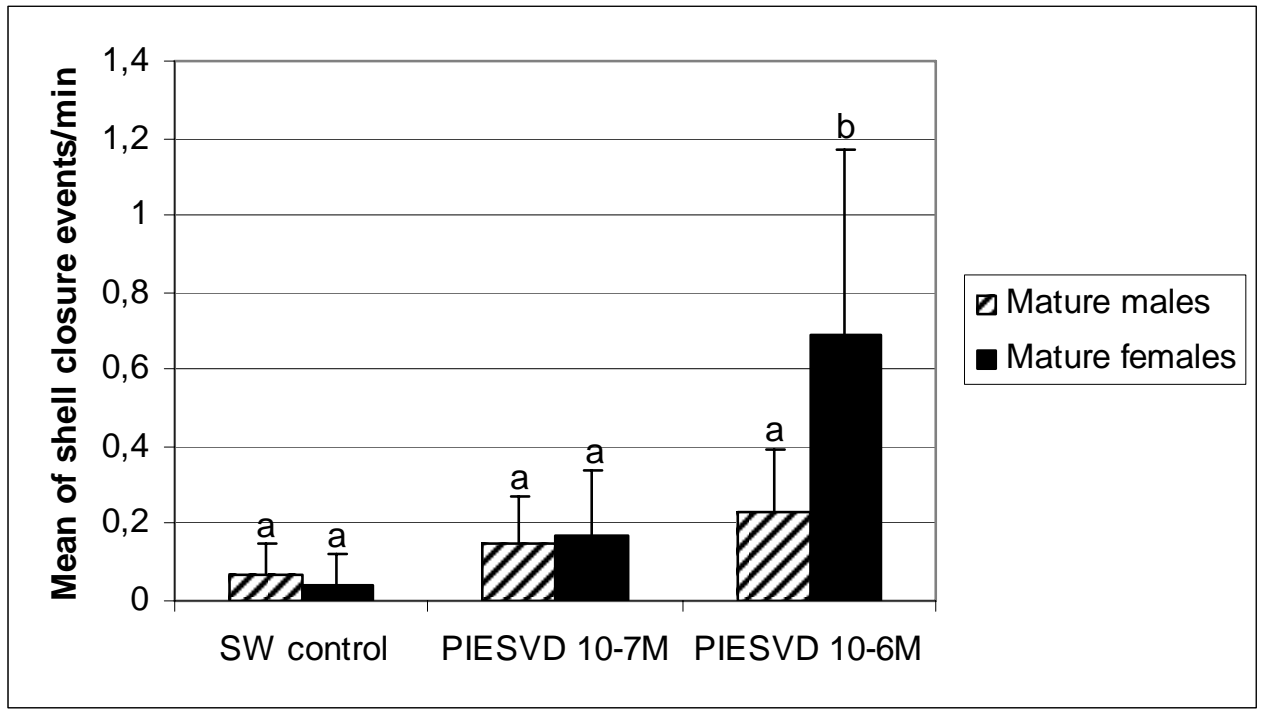

FIG. 8. PIESVD-induced contractions of oyster adductor muscle at a threshold of 10-6 M. Letters indicate significant difference between treatments (mean \pm S.D.; ANOVA, $\mathrm{p}<0.05$ ) 